\title{
Percutaneous transluminal angioplasty in the treatment of renovascular hypertension: sequential prospective study
}

\author{
Vascular Surgery, Department of Surgery and Nephrology, Department of Medicine, \\ Universidade Federal de São Paulo, Escola Paulista de Medicina, São Paulo, Brazil.
}

\begin{abstract}
Objective: to evaluate the use of percutaneous transluminal renal angioplasty (PTRA) in the treatment of renal vascular hypertension. Design: sequential prospective PTRA treatment of severe arterial hypertension, screening by the captopril test, confirmed by renal arteriography, and the result evaluated by post-PTRA arteriography, blood pressure measurement and renal function. Site: Vascular Surgery, angioradiology sector, and Nephrology outpatients department of the Federal University of São Paulo - Paulista School of Medicine, São Paulo, Brazil, a tertiary health-care institution. Participants: PTRA was employed on 32 patients screened by clinical examination, captopril test and renal arteriography. Evaluation: PTRA results were evaluated by the criteria of the Cooperative Study of Renovascular Hypertension. Results: after PTRA the completion arteriography showed no renal stenosis in 24 patients (75\%), residual stenosis $(20-50 \%)$ in $3(9.4 \%)$ and no change in $5(15.6 \%)$. The blood pressure results were: 3 patients $(9.4 \%)$ were cured, 24 $(75 \%)$ improved and $5(15.6 \%)$ were unchanged. We observed normal renal function before and after PTRA in 25 patients $(78 \%)$; altered pre- and improved post-PTRA in $2(6.3 \%)$; post-PTRA remained unaltered in $2(6.3 \%)$; and altered pre- and worsened postPTRA in $3(9.4 \%)$. Recurrence of stenosis occurred in one patient after 8 months. Conclusions: PTRA is a convenient procedure, relatively safe and an effective complementary method of medical therapy for controlling renovascular hypertension.
\end{abstract}

UNITERMS: Renovascular hypertension. Transluminal angioplasty. Renal artery stenosis. Atherosclerosis. Fibromuscular dysplasia.

\section{INTRODUCTION}

$\mathrm{T}$ he use of percutaneous transluminal angioplasty for the treatment of renal artery stenosis (PTRA) was first reported by Gruntzig et al (1) in 1978, and since then the results of PTRA have been reported by several centers ${ }^{(2-10)}$.

Address for correspondence:

Fausto Miranda Jr.

Rua Estela, 515 - bloco G - cj 81

São Paulo/SP - Brazil - CEP 04011-904
Acquired experience has reduced the complications rate and primary success has reached nearly $90 \%{ }^{(2-13)}$ with good results above $70 \%$ in longer follow-ups ${ }^{(14-20)}$. The treatment decision is taken by a multidisciplinary team, PTRA being the first choice except in cases of anticipated technical difficulties, treating one renal lesion at time in cases of bilateral lesion. PTRA has a low incidence of technical failure and renal loss, being the preferred route for inguinal catheterism. Balloon-catheter insufflation at the stenosis site breaks the intimal layer, the atherosclerotic plaque and the medial layer, dilating the renal artery ${ }^{(21,22)}$. Complications have been reduced and primary successes increased with greater experience and technological advance, using digital subtraction angiography, reduced quantities of injected contrast, adequate hydration and 
better materials ${ }^{(23)}$. Good results have been observed in children ${ }^{(19)}$, transplanted kidneys ${ }^{(24)}$, segmental renal branches $^{(25)}$, ostial lesions ${ }^{(26,27)}$ and even in short segmental obstructions ${ }^{(28)}$. PTRA is considered a long-term effective treatment for preventing renal function impairment and controlling blood pressure ${ }^{(19,24,25)}$.

The good results observed in the medical literature have led us to use this procedure and the aim of this article is to summarize our experience. with PTRA in the treatment of renovascular hypertension.

\section{PATIENTS AND METHODS}

Out of a total of 2,554 angiograms performed during a five year period, 137 patients $(5.6 \%)$ with arterial hypertension underwent screening renal arteriography. Percutaneous transluminal renal angioplasty (PTRA) was performed on 32 patients with renovascular hypertension

Table 1

Patient distribution according to age group

\begin{tabular}{cc}
\hline Age (years) & Patients \\
\hline $01-10$ & 1 \\
$11-20$ & 0 \\
$21-30$ & 8 \\
$31-40$ & 7 \\
$41-50$ & 8 \\
$51-60$ & 6 \\
$61-70$ & 2 \\
\hline Total & 32 \\
\hline
\end{tabular}

Table 2

Etiology of renal artery stenosis

\begin{tabular}{lc}
\hline \multicolumn{1}{c}{ Etiology } & Patients \\
\hline Fibromuscular Dysplasia & 16 \\
Atherosclerosis & 12 \\
Takayasu Disease & 2 \\
Renal Transplant & 2 \\
\hline Total & 32 \\
\hline
\end{tabular}

diagnosed by the clinical examination, renal function tests, captopril test and renal angiography.

The mean age was 36 years (range 1 to 70 ) (table 1 ), and the cause of renal arterial stenosis is summarized in table 2 .

The technique used for renal angioplasty did not differ from the classic techniques reported in the literature ${ }^{(29-32)}$. Acetylsalicylic acid $500 \mathrm{mg} /$ day was prescribed for six months after the procedure.

The results were evaluated in accordance with the criteria of the Cooperative Study of Renovascular Hypertension ${ }^{(33)}$ :

1 - The technical results before and after PTRA were quantified as: without stenosis, having residual stenosis $(20-50 \%)$, and unchanged.

2 - The blood pressure results were classified as cured (without antihypertensive drugs), improved (controlled with decreased doses of antihypertensive drugs), and unchanged.

3 -the renal function results before and after PTRA were classified by the creatinine dosage needed.

4 - the complications of the procedure and recurrence of the hypertension.

\section{RESULTS}

1 - The technical results of PTRA were shown by the completion arteriography: renal artery without stenosis in 24 patients $(75 \%)$, residual stenosis in $3(9.4 \%)$, and unchanged in $5(15.6 \%)$.

2 - The blood pressure results ranged from one month to five years (mean period of 16 months), showing: three patients $(9.4 \%)$ had diastolic blood pressure under $90 \mathrm{mmHg}$ without medication; in $24(75 \%)$ diastolic pressure under $109 \mathrm{mmHg}$ was achieved with decreased doses of antihypertensive drugs taken; and in 5 $(15.6 \%)$ the pressure was unchanged.

3 -Renal function results: we observed normal renal function before and after PTRA in 25 patients (78\%); impaired before and improved after PTRA in $2(6.3 \%)$; remaining impaired in post-PTRA in $2(6.3 \%)$; and impaired before and worsened after PTRA in $3(9.4 \%)$.

4 -Complications occurred in 10 patients and are listed in table 3 . In 5 (15.6\%), PTRA failed to achieve dilation of the stenotic lesion: two underwent surgical renal revascularization and one was submitted to a new PTRA successfully. The others were treated medically. 


\section{Table 3}

\section{Complications in 10 out of 32 patients treated with percutaneous transluminal angioplasty}

\begin{tabular}{lc}
\hline \multicolumn{1}{c}{ Complications } & Patients \\
\hline Nausea & 2 \\
Local Hematoma & 2 \\
Renal Artery Dissection & 2 \\
Renal Art. Perforation + Nausea & 2 \\
Renal Art. Perforation & 1 \\
Hematoma + Arterial Hypertension & 1 \\
\hline Total & 10 \\
\hline
\end{tabular}

Recurrence of stenosis occurred in one patient after 8 months, which was treated with another successful PTRA after the termination of this work.

\section{DISCUSSION}

Renal function impairment and the progression of renovascular disease has been associated with the clinical treatment of renovascular hypertension. PTRA and surgical treatment result in better control of arterial hypertension with lesser occurrence of cardiovascular events and mortality, preserving renal function ${ }^{(18,33,34)}$.

The use of PTRA in the treatment of renovascular hypertension has lower operative risk and the results are comparable to surgical treatment ${ }^{(8,18)}$.

To evaluate the results of PTRA the criteria of the Cooperative Study of Renovascular Hypertension were used $^{(33)}$. The technical results of PTRA depend upon the stenosis characteristics ${ }^{(29)}$, chiefly the etiology, our best results being the treatment of fibromuscular hyperplasia which was similar to other authors ${ }^{(14,15,19,25,31,35-38)}$. These good results, ranging from 89 to $100 \%$, may be attributed to younger age groups and lesser effects of hypertension on contralateral kidney and systemic vessels ${ }^{(21)}$. Recently, with a minor procedural risk, a cure rate of less than $30 \%$ has been obtained in the atherosclerotic group, which should be compared with rates greater than $50 \%$ in the fibromuscular dysplasia group ${ }^{(18)}$. No significant difference has been found between ostial and non-ostial PTRA treatment results of renal lesions ${ }^{(20,26,27)}$. These findings are different from some works relating ostial dilating difficulties compared with non-ostial lesions ${ }^{(15.29,39)}$, because ostial plaque is generally an extension of aortic plaque.

The PTRA cure rate is low, ranging from $6 \%{ }^{(40)}$ to $25 \%{ }^{(4,15)}$, and the best results have been obtained in fibromuscular dysplasia ${ }^{(25)}$. In our experience the cure rate was $9.4 \%$. The hypertension control with decreased doses of medication was a real benefit, as obtained in $75 \%$ of our patients treated with PTRA and in accordance with other authors $^{(21)}$ (table 4).

The PTRA complication rate ranged from $7.2 \%{ }^{(34)}$ to $46.2 \%{ }^{(16)}$, with local complications being the most frequent. We observed PTRA complications in 10 patients (table 3). However, the lack of comparability between patients in different series and the problem of definition of a "complication" leaves the discussion of this issue outside of the scope of this paper.

In 5 cases $(15.6 \%)$ it was not possible to dilate the renal stenosis, which is comparable to other authors' reports relating technically unsuccessful dilation ranging from zero to $15 \% \%^{(11-13,18-21,23-27)}$. In these cases surgical treatment or a new PTRA should be performed. In one of our patients, changing the femoral catheterization method

\section{Table 4}

Percutaneous transluminal angioplasty results in patients with atheromatous or fibromuscular dysplasia lesions collected from several authors

\begin{tabular}{lcccc}
\hline Lesion Type & $\begin{array}{c}\text { Cured } \\
(\%)\end{array}$ & $\begin{array}{c}\text { Improved } \\
(\%)\end{array}$ & $\begin{array}{c}\text { Unchanged } \\
(\%)\end{array}$ & $\begin{array}{c}\text { Total } \\
(\mathrm{N})\end{array}$ \\
\hline Atheromatous & 19 & 51 & 30 & 360 \\
Fibromuscular Dysplasia & 46 & 45 & 9 & 163 \\
\hline
\end{tabular}

Modified from Libertino \& Beckmann, 1994. (21) 
to the axillar route made the catheterization and dilation of the renal artery successful.

In the literature, a recurrence rate of 5 to $8 \%$ has been reported ${ }^{(9,15,20,41)}$. Generally, most recurrences take place within the first year ${ }^{(17)}$. Our patient with recurrence of renal stenosis 8 months after PTRA was successfully submitted to redilation after the end of this study. The use of PTRA and "stents" has been recommended for diminishing the recurrence of renal stenosis ${ }^{(42,43)}$, although these devices are at present expensive and are not available in the public hospital where we work.

In conclusion, PTRA is a relatively safe and convenient procedure and an effective complementary method of medical therapy for controlling hypertension.

\section{RESUMO}

Objetivo: avaliar os resultados da angioplastia transluminar percutânea (ATPR) utilizada para tratamento da hipertensāo renovascular. Desenho: Trabalho observacional prospectivo em que a ATPR foi empregada seqüencialmente em pacientes com diagnóstico clínico de hipertensão arterial de difícil tratamento, triados pelo teste de captopril e confirmados pela arteriografia renal, sendo o seu resultado avaliado pela imagem arteriográfica pós-ATP, medida da pressāo arterial e função renal. Local: setor de Angio-radiologia da Disciplina de Cirurgia Vascular e ambulatório de Hipertensāo da Disciplina de Nefrologia da Universidade Federal de São Paulo- Escola Paulista de Medicina, com atendimento de nível 3 de atenção à saúde. Participantes: foram incluídos no estudo 32 pacientes selecionados pelo quadro clínico, teste de captopril positivo e com estenose na arteriografia renal. Mensuração: para a avaliação do resultado da ATPR foram empregados os critérios do Estudo Cooperativo em Hipertensão Renovascular ${ }^{(33)}$. Resultados: Após a ATPR, a arteriografia de controle mostrou ausência de estenose renal em $24(75 \%)$, estenose residual $(20-50 \%)$ em três $(9,4 \%)$ e inalterada em $5(15,6 \%)$. Os resultados sobre a pressão arterial foram: três $(9,4 \%)$ pacientes curados, $24(75 \%)$ melhoraram e $5(15,6 \%)$ ficaram inalterados. Foi observada função renal normal antes e após ATPR em 25 (78\%) pacientes; alterada pré e melhorada após ATPR em dois $(6,3 \%) ;$ permaneceu inalterada pós-ATPR em dois $(6,3 \%)$ e estava alterada e piorou pós-ATPR em três $(9,4 \%)$. A recorrência da estenose ocorreu em um paciente após 8 meses. Conclusões: a ATPR mostrou-se um método conveniente, relativamente seguro e efetivo para controle da hipertensāo renovascular neste grupo de pacientes.

\section{REFERENCES}

1. Gruntzig A, Kuhlmann U, Vetter W et al. Treatment of renovascular hypertension with percutaneous transluminar dilatation of a renal artery stenosis. Lancet 1978;1:801-802.

2. Grim CE, Luft FC, Yune HY et al. Percutaneous transluminar dilatation in the treatment of renal vascular hypertension. Ann. Intern. Med 1981; 95:439-442.

3. Katsen BT, Chang J, Lukowsky GH et al. Percutaneous transluminal angioplasty for treatment of renovascular hypertension. Radiology 1979;131:53-58.

4. Martin LG, Price RB, Casarella WJ et al. Percutaneous angioplasty in clinical management of renovascular hypertension: initial and long-term results. Radiology 1985;155:629-633.
5. Schwarten DE, Yune HY, Klatte EC et al. Clinical experience with percutaneous transluminal angioplasty (PTA) of stenotic arteries. Radiology 1980;135:601-604.

6. Schwarten DE. Transluminal angioplasty of renal artery stenosis: 70 experiences. AJR 1980;135:969-974.

7. Sos TA, Saddekni S, Sniderman KW et al. Renal artery angioplasty. Techniques and early results. Urol. Radiol. 1982;3:223-231.

8. Tegtmeyer CJ, Dyer R, Teates CD et al. Percutaneous transluminal dilatation of the renal arteries. Techniques and results. Radiology 1980;135:589-599.

9. Tegtmeyer CJ, Kofler TJ, Ayers CA. Renal angioplasty: current status. AJR 1984;142:17-21.

10. Zeitler E, Richter EJ, Roth FJ et al. Results of percutaneous transluminal angioplasty. Radiology 1983;146:57-60. 
11. Becker GJ, Katzen BT, Dake MD. Noncorönary angioplasty. Radiology 1989;170:921-940.

12. Klinge J, Mali WPTM, Fuiglaert CBAJ et al. Percutaneous transluminal renal angioplasty: Initial and long-term results. Radiology 1989;171:501-506.

13. Boyer L, Bouchet F, Boissier A et al. Évolution de la créatininémie chez 140 patients hypertendus après succès technique de l'angioplastie transluminale percutanée de sténoses de l’ártère rénale. J.Radiol. 1993;74:609-613.

14. Martin EC, Mattern RF, Baer L et al. Renal angioplasty for hypertension: predictive factors for long-term success. AJR 1981;137:921-924.

15. Tegtmeyer CJ, Kellum CD, Ayers C. Percutaneous transluminal angioplasty of the renal artery. Results and long-term follow-up. Radiology 1984;153:77-84.

16. Mahler F, Probst P, Haertel M et al. Last improvement of renovascular hypertension by transluminal dilatation of atherosclerotic and nonatherosclerotic renal artery stenosis. A follow-up study. Circulation 1982;65:611-617.

17. Colapinto RF, Stronell RD, Harries-Jones EP et al. Percutaneous transluminal dilatation of the renal artery: follow-up studies on renovascular hypertension. AJR 1982; 139:727-732.

18. Silva HB, Frimm CC, Bortolotto LA et al. Angioplastia percutânea e revascularização cirúrgica em hipertensão renovascular. Experiência no tratamento e seguimento de longo prazo em 124 pacientes. Arq Bras Cardiol 1994; $62: 417-423$

19. Casalini E, Sfondrini MS, Fossali E. Two-year clinical follow-up of children and adolescents after percutaneous transluminal angioplasty for renovascular hypertension. Invest Radiol 1995;30:40-43.

20. Von Knorring J, Edgren J, Lepäntalo M. Long-term results of percutaneous transluminal angioplasty in renovascular hypertension. Acta Radiol 1996;37:36-40.

21. Libertino JÁ, Beckmann CF. Surgery and percutaneous angioplasty in the management of renovascular hypertension. Urol Clin North Am 1994;21:235-243.

22. Xicai C, Enhui W, Jiwu C et al. Experimental renal artery stenosis and angioplasty. The mechanism of the angioplasty. Chin Med J (Engl) 1995;108:113-116.

23. Tedeschi AL, Peixoto ECS, Rachid MBF et al. Angioplastia renal transluminal percutânea no tratamento da hipertensão renovascular. Arq. Bras. Cardiol 1993;60:327-333.

24. Raynaud A, Lucino S, Almeida Augusto MC et al. Angioplastie endoluminale percutenée des reins transplantés. Suivi à long terme. J Radiol 1994;75:81-86.

25. Cluzel P, Raynaud A, Beyssen B et al. Stenoses of renal branch arteries in fibromuscular dysplasia: results of percutaneous transluminal angioplasty. Radiology 1994; 193:227-232.

26. Hoffman O, Raynaud A, Tsocanakis O et al. Sténoses ostiales des artères rénales: traitement par angioplastie. J Mal Vasc 1994;19(suppl A):90-91.

27. Eldrup-Jorgensen J, Harvey HR, Sampson LN et al. Should percutaneous transluminal renal artery angioplasty be applied to ostial renal artery atherosclerosis? J Vasc Surg 1995;21:909-914.
28. Lasry JL, Qanadli S, Lafitte F et al. Occlusion de l'artère rénale: revascularisation percutanée. J Mal Vasc 1994; 19(suppl A):129-135.

29. Sos TA, Pickering TG, Sniderman K et al. Percutaneous transluminal renal angioplasty in renovascular hypertension due to atheroma or fibromuscular dysplasia. N Engl J Med 1983;309:274-279.

30. Sos TA, Saddekni S, Pickering TG et al. Technical aspects of percutaneous transluminal angioplasty in renovascular disease. Nephron 1986;44(suppl 1):45-50.

31. Srur MF, Sos TA, Saddekni S et al. Intimal fibromuscular dysplasia and Takayasu arteritis: delayed response to percutaneous transluminal renal angioplasty. Radiology 1985; 157:657-660.

32. Tegtmeyer CJ, Sos TA. Techniques of renal angioplasty. Radiology 1986;161:577-586.

33. Maxwell MH, Bleifer KH, Franklin SS et al. Cooperative study of renovascular hypertension. Demographic analysis of the study. JAMA 1972;220:1195-1204.

34. Madias NE, Kwon OJ, Millan VG. Percutaneous transluminal renal angioplasty: a potentially effective treatment for preservation of renal function. Arch Intern Med 1982;142:693-697.

35. Luscher TF, Keller HM, Imhof HG et al. Fibromuscular hyperplasia: extension of the disease and therapeutic outcome. Results of the University Hospital Zurich Cooperative study of fibromuscular hyperplasia. Nephron 1986;44(suppl 1):109-114.

36. Millan VG, Most WE, Madias NE. Nonsurgical treatment of severe hypertension due to renal artery intimal fibroplasia by percutaneous transluminal angioplasty. N Engl J Med 1979;30:1371-1373.

37. Saddekni S, Sniderman KW, Hilton S et al. Percutaneous transluminal angioplasty of nonatherosclerotic lesions. AJR 1980;135:975-982.

38. Tegtmeyer CJ, Elson J, Glass TA et al. Percutaneous transluminal angioplasty: the treatment of choice for renovascular hypertension due to fibromuscular dysplasia. Radiology 1982;143:631-637.

39. Cicuto KP, McLean GK, Oleaga JA et al. Renal artery stenosis: anatomic classification for percutaneous transluminal angioplasty. AJR 1981;137:599-601.

40. Grim CE, Yune HY, Donahue JP et al. Renal vascular hypertension. Nephron 1986; 44(suppl 1):96-100.

41. Buist T. Percutaneous renal angioplasty. J.R. Soc Med 1985; 78:353-354.

42. Rees CR, Palmaz JC, Becker GJ et al. Palmaz stent in atherosclerotic stenosis involving the ostia of the renal arteries: preliminary report of a multicentric study. Radiology 1991;181:507-514.

43. Espinosa G, Mariz A, Murad H. Angioplastia e implante primário de prótese endoluminar de Palmaz no tratamento da estenose proximal da artéria renal: resultados preliminares. Cir Vasc Angiol 1996;12:171-179. 